\title{
Gender Gap and Trade Liberalization: An Analysis of some selected SAARC countries
}

\author{
Marc Audi, Ph.D \\ AOU University/University Paris 1 Pantheon Sorbonne
}

\author{
Amjad Ali, Ph.D \\ School of Accountancy and Finance, University of Lahore, City Campus.
}

\begin{abstract}
Trade liberalization plays a significant role in the development of an economy as all countries have insufficient resources and depend on trade to grow and prosper. The key objective of this study is to explore the relationship of trade liberalization on women empowerment. It also aims to find out whether it is beneficial for gender gap or not. This study utilizes the sample of five SAARC countries for the time period of $\mathbf{1 5}$ years, that is, from 2000 to 2014 . It emphasizes on tariffs and regulatory trade barriers, which are considered significant indicators of trade liberalization, along with the freedom of trade, that is a composite index. The gender gap is measured through the female to male participation rate, whereas, gender development index(GDI) is used as a relative measure of women empowerment after adjusting HDI for gender disparity in three dimensions. The other control variable incorporated in this study includes: gross domestic product growth, education of female, female unemployment rate and the hiring regulations \& minimum wage standards. The econometric technique applied is the pooled ordinary least squares (OLS) method along with various diagnostic tests. When trade liberalization goes up, it increases the GDI, meaning lower gender disparity, which in turn refers to greater women empowerment. The research concludes that whenever the trade liberalization increases, it does not reduce the gender gap, which means the female to male participation rate goes down. It encourages women to actively participate in the labor market, but it does not play a role in reducing gender gap. Education of female is essential because it creates awareness among girls and enhances their skills, which leads to empowering women, making them self-sufficient and active participants in the economic activity, which can improve their standard of living.
\end{abstract}

\section{INTRODUCTION}

Trade plays an enormous role in the growth and development of the economy. As the time is changing, there is no country in the world that is completely self- sufficient to adequately fulfill the requirements of its citizens. Therefore, the countries have to indulge themselves in some sort of exchange of goods, services and capital as no country has it all. Countries have exported these goods and services in which they are self- sufficient and have a surplus. This exchange is commonly known as foreign international trade. At the present time, international trade is an indispensable transaction between countries (Siddiqi, 2009).

Every country involved in a trade, profits in a way or another. Starting from the barter trade to the trading practices today, countries have enjoyed numerous advantages. Some imperative benefits of international trade include:

- The competition within the domestic industries leading to high quality products at affordable prices keeping them cost effective.

- Due to advanced technological variations, producers and suppliers fully utilize the modern machinery and technology. 
- Boosting the sales and profits of everyone involved, as more products are available and consumers can get whatever they need immediately with the least effort.

- The latest marketing and advertising tactics help the seller enhance the sale of existing items.

- Businesses have greater opportunities of expansion due to increased demand.

- There is an easier access to the international markets that can bring more prosperity to business and to the economy as well.

- The trade helps in stabilizing the fluctuations and variations due to seasonal changes (Benefits of free trade, 2013).

Trade liberalization considered to have many beneficial aspects on the economic growth. It is described as the removal or lessening of various trading barriers or restrictions in order to pave the way for free trade that is the free exchange of goods, services or other resources among countries. The restrictions include both the tariff and non- tariff barriers. The trade barriers are imposed mainly to protect the domestic industries from intense competition. Those barriers are divided into various sub-sections like tariff barriers (taxes or duties levied by government on globally traded products and include import duties, transit duties and export duties), non-tariff barriers (not levied directly on products but these restrictions are imposed in other forms such as quotas, boycott, monetary barriers, voluntary export restraints, dumping and other standards). When the government reduces and completely lifts these restrictions on trade, it is opening the door for free trade (Siddiqi, 2009). Trade liberalization has numerous benefits including increased competition leading to enhanced quality products, increased employment opportunities, easier exchange of technology, economic growth, and lower prices of products, specialization, economies of scale, greater revenues and efficient resource allocation. However, it also has some disadvantages, such as, exploitation of local industries, sometimes the competition is unfair, unequal division/distribution of benefits and various environmental issues (Essays, 2013).

Gender gap is referred to as the disproportionate discrimination among males and females. In the work environment, it is known as the disparity among the genders on the basis of salaries, or on the opportunities of work. In most cases, men earn greater than women do. Similarly, gender gap can also exist in the area of education as the chances and prospects available for males are much better and larger in number as compared to females. In most of the developing countries, females are not allowed to go to school or get any sort of education, due to which they lag behind and they are not given a chance of improving in their working life with reasonable wages. According to economists, gender gap is generally the difference in the goals achieved by the male and female in the labor market (Goldin \& Katz, 2008). The situation of gender gap in developing countries is much more critical especially in the areas of health, education and in human rights as well.

According to Elson \& Evers (1996), gender gap can be put into three main levels such as, macro, meso and micro. Macro level refers to the gender inequality existing between the productive and reproductive sectors of the labor market. Meso level is related to the discrimination while assigning duties and distributing resources, labor and decision making as a whole. Additionally, numerous researches suggest a negative association among gender gap in education and employment and overall economic growth (Hill \& King, 1995; Galor \& Weil, 1996; Klasen, 1999; Dollar \& Gatti, 1999; Lagerlof, 2003). Endorsing this point, Korinek (2005) states that gender inequality hinders the economic growth process. In terms of education, if a female is educated, she will have greater authority over household decisions and she will spend wisely on the education and the health of her children, which is similar to investing in the future labor force and upcoming generations making them more productive. Moreover, if 
the female participation is less in the economy, the country's resource allocation will be inefficient leading to a decreasing economic progress. Usually, the female working in these professions are low-paid as they have lesser access to education and skills attaining opportunities. As of males, they have an easier access to education, skills, and therefore, they are hired in highly paid professions and sectors. Female also have restricted access to land and property due to inheritance laws and various legal frameworks (Korinek, 2005). According to Peebles (2005), women also have limited access to financial services, business networks and other resources evading them from making any purchase of capital or goods or making huge investments.

In SAARC countries, gender inequality or discrimination can be seen in labor market in terms of employment as well as in various other aspects. The work done by women is more as compared to their salaries, unjust resource allocation at the domestic level, unequal rights of various public services like health and education and also in case of restricted role in decision making. Despite an increase in education and literacy rates, women participation in leadership, political decisions, employment opportunities and empowerment is still low in SAARC countries compared to developed countries (Ahmad \& Hyder, 2006; Tariq \& Sultan, 2008). This pattern is evident not only in the OECD countries but also in the developing countries (Korinek, 2005). If women are given access to education, employment, trade and other decision-making roles, along with reducing trade barriers, they can play a significant role in enhancing the economic growth.

The earlier researches have focused mostly on wage inequalities or on other aspects of trade openness. The developing countries are not utilizing the advantages of trade liberalization to the fullest. Gender gap is among the most crucial reasons. This research is an addition to the existing literature as it not only assesses the impact of freedom to trade which is a key indicator of trade liberalization, but also studies the individual effects of its sub-indicators such as tariff and regulatory trade barriers. It also combines the other factors that may have an impact on gender gap, like female education, hiring policies and minimum salaries, GDP growth and the female unemployment rate. It will be useful in devising policies to create awareness among the authorities about the importance of women's role in the economy, if they are provided with higher education, employment and better training opportunities on equal basis along with identical wages as men, only then the benefits of trade liberalization will be fully incorporated.

Trade liberalization play a key role in the economic growth of any country, by involving the various sectors and individuals from all walks of life. In the recent times, numerous studies (Tzannatos, 1998; Korinek, 2005; Ahmad \& Hyder, 2006; Schultz, 2006; Saure \& Zoabi, 2009; Rehman, 2014; Pieters, 2015) have suggested its significance in influencing the gender gap and empowering women. It is said that trade openness with limited tariffs and regulatory barriers can reduce the gender gap by empowering more women. However, trade liberalization alone cannot achieve this goal. Researches also indicate that the female population is more than 50 percent in the most of the developing countries like Pakistan, but this large share of population does not have access to employment opportunities and if women are employed, they are employed in informal sectors that receive low wages due to less wider access to education, skills, time and resources. Increased trade openness and more trading opportunities along with escalated output may lead to greater participation of female in paid workforce (Korinek, 2005). Gender differences are striking worldwide where the employment standards vary enormously for male and female. This study will address this issue and analyze that to what extent trade liberalization as a whole in terms of freedom to trade or partially in the form of tariffs and regulatory trade barriers affect the gender gap and whether it empowers women or 
not? The study will also take into account the impact of female education, unemployment rate, economic growth along with hiring regulations and wage standards.

Keeping in view the increasing importance of trade liberalization and its influence on economic growth of the country, this research will combine this area with another indispensable and highly debatable issue of gender gap. Even though this argument has been going on for a long period, the developing countries are not fully utilizing the countless advantages of trade openness because of gender differences. This research aims to explore the relationship of trade liberalization \& gender gap and whether it empowers women by gathering evidences from the SAARC countries. The major research questions are: Does the trade openness empower women? Does trade liberalization have an impact on gender gap? What are the other factors that may an influence on gender gap? What are the other factors that may have an influence on gender gap and women empowerment?

\section{LITERATURE REVIEW}

Fonatana et al., (1998) conducted a qualitative research by assessing case studies from Ghana, Sri Lanka, Pakistan, Uganda, Jamaica and Bangladesh, focused on understanding the significance of gender evaluation and why countries fail to take full advantage of trade opportunities along with the role of distraction and hindrance in factor markets due to gender difference. In addition, it explains why the advantages of trade liberalization are distributed differently among men and women and why they have varied consequences towards the world's gender equality and poverty reduction. Large number of variables are incorporated in the study. The findings are not very elaborative and need additional research. However, it gives recommendations like:

a) The countries in which female labor participation in export led industries is greater, labor market inequalities should be reduced.

b) The countries which are agriculturally intensive, property rights for women must be changed and strengthened. Strategies must be formulated to decrease gender inequalities for trade expansion and ways must be devised to encounter the negative consequences. Gender equalities should also be observed in case of labour standards leading to bigger corporate responsibilities.

Tzannatos (1998) explored the level of variation in female and male labour participation rate, job segregation and salaries of female versus male all over the world by using the data from all continents from the census of 1950/1960 and from 1980/1990 and the variable included in the study are labour force participation rates, age, category of job, total labour force, influence of eliminating job segregation and salaries of female. The outcomes suggested that labour market of developing countries flourished relatively faster as the gaps prevailing in the jobs and wages are decreasing quickly. The growth process is highly advantageous for female, whereas, gender gaps lead to worst influence on well-being.

Dollar and Gatti (1999) tried to answer the three major question like:

a) If restricted investment for education of the girls is useful solution for economic progress in developing countries

b) If the gender gap is true reflector of cultural and social priorities about the roles of male and female

c) Does market failure tend to cause low investments on female, which may decrease if these countries progress. 
To answer these queries, data from 80 countries is collected for the year 1990 and econometric techniques applied are OLS, fixed effects and 2SLS. The finding respond to the initial question as:

a) Countries which invest less take more time to grow

b) Under investment in girls does reflect societal priorities to some degree and if it increases it will worsen the situation

c) Market failures might influence investments on female, whereas, increasing wages can lessen gender inequality, also these failures might reduce as a country progresses.

Seguino (2000) found that lower salaries for female have incited the export and investments by decreasing the product cost, giving foreign exchange for purchases and enhancing the level of productivity. These outcomes are inconsistent with the recent studies indicating income equality for encouraging development process and reducing political instability. The reason behind such opposing outcomes can be linked to the acceptance of lower wages by female due to societal values and restrictions leading lesser political instability and up surge in investments. The study states that the gender that experienced inequalities matters the most in the growth process. The study conducted on the data set of twenty Asian countries from 1975 to 1990.

Black and Brainerd (2002) conducted a research to answer if up surged trading activities tend to lessen the degree of discrimination and in turn led to an increase in salaries of female, and whether the markets play its role if federal government fails to do so while pressurizing the employers to lessen discrimination so that they could sustain in the ever increasing competitive environment. Regression analysis has been applied on the data gathered from 1977 to 1994 . The study indicates that trade influence competition, which lead to an increase in female salaries in competitive sectors and firms and in this aspect, trade can be advantageous for female by reducing inequalities within companies.

Orbeta (2002) conducted a research to find out the influence of trade on level and structure of employment in Philippines at the manufacturing industries. Variables incorporated in this study include real wage, shifters, real GDP, output, lending rate of banks, exports and imports with respect to GDP, and various trade indicators on the data gathered from 1980 to 2000, whereas, the data on manufacturing industries is from 1993 to 1997 and perform regression analysis on the demand labour function with shifters. If the propensity to export increases, the demand function shifts towards, whereas, mixed results are found in case of propensity to import. Trade openness have insignificant influence on female at the aggregate level but it is advantages on industry level. Moreover, boosted propensity to export increases the proportion of workers with lesser skills in aggregate as well as in manufacturing industry level.

Another qualitative research is conducted by Fontana (2003) to evaluate the recent progressions of employment variations, gender gap with reference to wage discrimination and domestic modifications as a result of trade liberalization in different developing countries. The study illustrate that trade liberalization has improved the working conditions for female in labor intensive sectors, but the impact of trade is restricted for female in case of property rights. Moreover, the influence of trade openness for female is higher in manufacturing sectors as compared to agricultural sector but the research is limited in this field. Wage gap is lower in trade related industries, contrarily, it is considered to be reliant on the level of job segregation.

Bolaky and Freund (2004) used a dataset of 108 countries for a period of 2000 and 2001. The research employed cross sectional analysis, cross sectional analysis with instrumental variables and growth analysis on variables such as, trade openness, interaction term between 
trade openness and regulations, per capita real income, regulation index, population, distance to equator, position of law and whether the country is landlocked or not. The outcome of study indicates that too much regulations hinders the growth process as there are hurdles in the movement of products and resources to productive sectors and efficient companies. Moreover, it is expected that in regulated countries, investment and trade generally occurs of inappropriate goods. It is suggested that regulatory reforms can boost the advantages of trade openness.

Fofana et al., (2005) aim to review the influence of trade liberalization on female and male working conditions in Nepal. By keeping the structure of Nepalese economy, this study explains the difference between female and male work, salaries and time spends on leisure and household chores. The research incorporates the computable general equilibrium model for this purpose with a combination of different variables. The result of this study indicate that complete removal of tariffs in Nepal is more advantageous to female than male with reference to increase in salaries, consequently reducing the leisure time of female. Additionally, the leisure time of male increases with trade reforms.

Korinek (2005) explained in the paper that how trade openness and trade liberalization lead to gender equalities and their consequences within special emphasis on gender wage inequalities along with other types of gender differences by choosing a number of countries run on exports from Africa, Asia, Caribbean and Latin America. The research findings illustrate that countries which are export oriented tend to have more job opportunities for female after trade openness as it gives them control in their household matters especially for the health and education of children, which indirectly means investing in future. Wage discrimination is still preventing along with limited access of female to various resources in developing countries. Female also encounter inequalities in terms of hiring and promotions in many OECD countries. However, effective strategies must be designed to lower this discrimination and for the improvement of female's standard of living.

Spielmann and Busse (2005) explored the global connections among gender gap and trade policies by focusing on comparative advantage aspect of labor- intensive goods. The study incorporates a dataset of 92 developing countries and employed the cross sectional analysis and panel fixed effects analysis for finding this association. Variables used in this study consist of capital, labor, GNI, education, wages, time, labor inequality, wage inequality, education inequality and two indicators of trade to measure comparative advantage. It is found that gender gap is positively linked with comparative advantage of labor intensive product meaning countries with huge wage gap will have more exports. On the other hand, labor and educational inequality are negatively associated with comparative advantage of labor intensive products. Furthermore, Staveren (2005) conducted a qualitative research by reviewing and evaluating five methodological techniques to explain the association among trade and financial liberalization along with trade and gender. The approaches under consideration are structuralism approach, golden straight jacket approach and trade elasticity approach. Two empirical approaches include policy based approach and outcome based approach. The reviews suggested that it is upon the user and reader to choose between these approaches as no approach completely explains the association existing among, trade, gender and financial liberalization.

Ahmad \& Hyder (2006) studied the influence of trade liberalization on gender inequality, as a case study of Pakistan. A regression analysis is applied on the variables such as gender inequality index, GDP, exports, imports, number of schools for girls and boys, and the number of teachers working in each school for the time period of 1973 to 2005 . The research illustrates 
that with the passage of time, gender inequality which was very high previously is declining. Trade openness and liberalization of trade policies have contributed a lot in this regard. Income inequality has also been decreased on the whole.

Atieno (2006) explored the major factors behind female participation level in various informal sectors and industries along with broad range of other labor markets aspects in Kenya for the year 1997. Using female participation in various sectors, with age, type of firm and sectors, level of education, bread earner of family, marital status, financial and other assets along with the number of children, the study came to following outcomes. Education plays an essential role in the level of female participation in the job market, emphasizing on the fact that in order to enhance female participation and their effective contribution, education should be made easily accessible for them along with boosting their human capital. The demand side of labor market in Kenya should also be observed for encouraging the female involvement in economic development.

In order to determine the linkage among trade liberalization and role of women in economic growth of a country, Schultz (2006) gathered data of 70 countries for a period from 1965 to 1980 with an interval of five years. This study uses the variables like population, GDP per adult, schooling attainments, foreign exchange laws, enrolment rates with the specification of gender, tariffs, exports including imports, quota and human capital and applied the econometric techniques of OLS and 2SLS. The chosen variables depicted a mixed behavior, however, trade liberalization is expected to boost as a result of gender equality. Another study on the impact of globalization on gender gap and economic development is conducted by Seguino and Grown (2006). This research aims to determine ways of improving the standard of living and wellbeing of women, while enhancing economic activity as well. It is a qualitative research as it reviews and analyze various theories with their probable outcomes. Assessment of theories suggest that the states plays a crucial role in economic activity, and the development of any country is greatly dependent on its structure and type of gender inequality and segregation. However, the study mentioned that a strategic framework has to be devised with following points in mind: a) boosting productivity in female intensive sectors and industries, b) encouraging those sectors and industries that can pay higher salaries to employees, c) and permit full time employment via demand side strategies.

To understand the association between gender and globalization in South Asia, Siegmann (2006) conducted a research to find out how international economic integration is connected with gender inequalities in the selected region. Using the labor market indicators like wage equality, working environment and job opportunities because they are considered to be greatly affected from trade strategies. The data set included South Asian countries from a time period of 1991 to 2002 and the research found that in almost all sectors, female employees have lower rank, prolonged working hours, lesser job security and poor working environment. Limited access to education along with gender inequalities and restricted control over bargaining powers in labor market add to this problem for female. The outcome state that globalization leads to greater opportunities if one has access to resources of all kind, so to get benefit of these opportunities, the access to these resources for female must to be encouraged. Resources include easier accessibility for education, capital, land, legal rights and freedom of movement.

Similarly, Neumayer and De Soysa (2007), investigates the basic labor rights in connection with discrimination against female and occurrence of forced labor. By employing a comprehensive dataset of 143 countries in which 120 are developing countries and various econometric techniques like order logit model, random effects with instrumental variables estimations are applied. Major variables are trade openness, accumulated stock of FDI with 
respect to GDP, women rights, per capita income, democracy, Muslim percentage and dummy variables. The outcome of this research indicate that countries with trade liberalization tend to have more economic rights for female with lesser chances of forced labor. As trade openness and easy access to international markets are more inclined towards labor rights.

El-Hamidi (2008) explored if the trade liberalization influence more on those sectors which have more hiring from one gender as compared to other sectors and what is the level of impact of sectors involved in trading and facing more competition in reducing gender discrimination in salaries and as a whole. The data has been gathered for a time period of 1998 to 2006 and results of this research states that the sectors indulged in trade experience greater gender inequality in salaries as compared to other sectors. Also, wage discrimination is detected in almost all the sectors of employment.

Moreover, Burgoon and Hiscox (2008) studied the variations in opinions about international trade and major reasons behind gender inequality, by using variables like favor trade, age of female, education, rate of employment, salaries, number of hours, parental leaves, job security, political views, religious inclination, type of sector, and NAFTA knowledge. The dataset consists of 1610 American adults for the year 2003. The research found that gender inequality prevails even after controlling for employment variations, whereas, maternity and political views have no influence on gender gap. However, it is observed that exposure to information and economic issue might leave an impact on the connection among gender gaps and trade.

Another research is conducted to determine the connection among trade liberalization and economic growth by Wacziarg and Welch (2008). The research employs a relatively new dataset with modified indicators over a large period of time, that is, from 1950 to 1998 in 24 countries and fixed effects regression technique is applied. The variables incorporated are different types of liberalization such as investment, openness, growth, various trade policy variables like average tariffs, openness, average BMP, marketing, socialism, core non- tariff barriers rate, per capital gross domestic product, and physical capital investment. Findings state that the countries who opted for trade liberalization in the chosen time period experienced a relatively greater growth as compared to other countries. This endorses the point that liberalization plays a key role in growth via physical capital investment. Also, countries who experienced positive growth emphasized on intense trade reforms, while other countries encountered political instability, and implemented contractionary policies at the macroeconomic level.

Berik et al., (2009) studied the linkage among the inequality prevailing within groups and their macroeconomic impact with the help of interaction of different channels like gender, development and growth by reviewing extant researches. The research concludes that discrimination at any level restricts the capacity to deliver and progress and suggests that macroeconomic policies play a crucial role in attaining gender equality and how it can have a macro influence on education and salaries. Additionally, it states that these policies are reliant on the type of economy and job segregation, the measures adopted to determine gender inequality and foreign relations. The study also devises policies to encourage gender equality and how to enhance the standard of living.

Ederington et al., (2009) examined if increasing competition will decrease the discrimination as suggested by Becker's theory. The study also aims to find if trade openness and liberalization have some sort of influence on hiring procedures in Columbia by using data from the time period of 1984 to 1991 . The variables like share of female, age of firms, exports, wages, employment rate, level of energy used, type of office equipment, firm type, productivity, 
turnover ratio and female management have been used. The outcomes of this study are consistent with the theory, whereas, the influence of trade liberalization is greater for firms who do not export goods. It is in line with the initial analysis that up surging competition will have greater influence on firms with low competition at the beginning.

Adding to the literature on gender inequality and economic growth, Klasen and Lamanna (2009) investigated the contribution of gender inequalities in employment and education in inhibiting economic development and to fill the gap in the existent literature regarding this issue. Incorporating the data from a large panel of countries for the period of 1960 to 2000, the study found considerable evidence suggesting that gender gap in employment and education restricts economic growth. The variables used to study this relationship include, real per capita GDP, investment rate, compound growth rate, population growth rate share of export and imports, fertility rate, working age population growth rate, mortality rate of children before age 5, life expectancy rate, number of schooling years (also, schooling years of female and male separately), male and female economic activity rate, female labour force participation rate and growth rate of male and female schooling years.

Another study is conducted by Saure and Zoabi (2009) to fill the gap in the present literature about the rate of female labour force participation and global trade. By incorporating the data from 51 states of U.S. and applying the OLS regression analysis, it is found that the influence of global trade on the share of female in labour market is counter intuitive which means the share of female declines in female intensive sector as a result of trade expansion and vice versa. It is also associate with the reallocation of male to the female intensive sector after these expansions. The fall in the capital labour ratio leads to a decrease in female labour involvement on the whole and enhances the wage gap between genders. The variables used in this research are female education, working hours, Mexican immigrants' share, distance to Mexico, female labour share, rate of unemployment, trade volume, and per capital gross state product.

Earlier research by Aguayo-Tellez et al., (2010) focused on the distributional influence of trade liberalization on gender inequalities keeping three major objectives in mind which are; position of the result from female' inclusion in labour market during the reform process, connection between those result and trade liberalization and how to enhance the well-being of female. In this study, surveys are conducted along with regression analysis on the data gathered from two censuses (1990 and 2000) for a period of 1984 to 2004 in Mexico. By using a large number of variables, the research came to a conclusion that wages are consistent and female employment is up surged, reduction in tariffs and export duties leads to positive industry growth leading to huge advantages for female as most of these industries have intense female involvement. The control over expenditures at the household level is shifted from male preferred goods to female preferred goods like education, health and clothing.

Aguayo-Tellez (2012) examined various latest research on the effect of trade liberalization and FDI on the gender gap with respect to health, wages, employment, education and different welfare aspects in both developing and developed countries. The assessment of recent studies suggest that the impact of trade liberalization is different for every country, whereas, the influence is higher in developing economies. Moreover, even on the developing countries, the effect is varied as in some regions women benefit from the trade openness, but in others, it affects negatively. Skills also play a major part in deciding which group of female have added advantages. If women have educational opportunities, they will not only get satisfactory jobs but also better salaries reducing the wage gap leading to an overall dwindling of the gender inequality. 
Chakraborty (2012) determined the effect of industrialization resulting from the latest modification in the trade laws and policies on the inclination towards a male child in India for the year 1999. The econometric technique applied is the OLS regression analysis by incorporating variables like caste, Hindu population, industry of work, number of children, wages, tariff measure per district, migration effect, priority towards the male child, dowry, mortality rate of female infants, tariffs effect on nonagricultural sectors and growth rate in manufacturing sectors. The study concluded that odds of survival for female is decreased due to trade liberalization which has a great effect especially on religious grounds. It is possible that trade openness and industrialization will upsurge the mortality rate between female and male child.

Contessi et al., (2012) studied the association between openness of trade and globalization and female labor participation by emphasizing on the following two characteristics: the examination of comparative advantage in female labor force by incorporating both cumulative and firm level data and the role of trade openness in supporting female ownership and entrepreneurship through a survey analysis of MENA countries including Tunisia, Egypt, Algeria, Syria, Jordan, Yemen, Morocco, Lebanon, and Turkey from 2006 to 2009. Selected variables are density and frequency of female workers, occurrence of female ownership, entrepreneurship and top management, within industry distribution, female labor force in exports along with the hindrance in opportunity and growth. Finding suggests that female can become owners in businesses in countries with extensively available female labor with limited restrictions and in industries with large number of female. Strong connection can be found amongst measure to enhance female labor involvement ratio and country's specialization as suggested by factor endowment trade and technological basis theories. The trade liberalization inexplicably influences companies and industries within a country with respect to female labor participation either it is employment or ownership/entrepreneurship.

Additionally, to describe the association between trade liberalization and female labor force participation and in turn lessen the gap in literature regarding this relationship, Gaddis and Pieters (2012) applied the econometric technique of first stage TSLS on the data collected from Brazil for a time period of 1987 to 1994 . The variable used for this research are age, ethnicity, education, children, labor market result, type of work, marital status, employed or jobless, along with tariff variations in the chosen period. The research states that tariff modifications have a different influence on male and female due to dissimilarity in their sector of employment. Female remain the secondary wage earners even after marriage. Reducing gender gap in favor of female is highly significant but the actual motivation for them to enter the labor force is also essential.

Similarly, Juhn et al., (2013) aimed to study gender gap which is a relatively less explored area as compared to wage gap, and its effects on trade liberalization as prescribed by NAFTA in relation with export and import tariffs. A survey analysis is conducted in this study with the help of national survey of wages, employment, training and technology database and chosen variables are ratio of female to male in terms of wage bill and employment outcomes, import and export tariffs, a detail set of company characteristics like capital and R\&D intensity, size and level of foreign ownership of the company. The findings of this research are in compliance with earlier researches reinforcing that NAFTA agreements encourages female employment due to a reduction in tariffs.

To study the effects of globalization determined by foreign direct investment, urbanization and trade openness on the female labor force participation rate, Maqsood (2014) used the data for a time period of 1990 to 2010 in the SAARC countries. The econometric technique employed is 
Panel Fixed and Random Effects and variables incorporated for this research are; female labor force participation measured as the percentage of female who are employed, trade openness defined as the level of imports and exports with respect to GDP, FDI determined by the net inflows in any country and urbanization is the population of urban area. The result of this study indicate that urbanization and foreign direct investment are positively associated with female labor force participation rate, however, the impact of trade openness is opposite. Trade liberalization creates competition increasing labor force participation and greater involvement in training opportunities.

Rahman (2014) determined the relationship among gender gap and trade liberalization in Bangladesh with special emphasis on the industry of ready-made clothes as it incorporated the highest number of female workers, has 77.12 percent share in overall export revenues and has a 14 percent share in GDP. The study found that trade liberalization increased the female involvement in this sector by five times, but the discrimination with female is still high in terms of work environment. Conversely, the income gap among female and male is low and this is mainly due to the longer work shifts of male, female workers lacking skills and education, disbelief and bad behavior of employees towards females' capabilities.

Pieters (2015) studied the prospects of trade liberalization influencing gender inequality in the work force. Also, the research aims to find out the outcome of discrimination and dissimilarity in skills between the female and male employees. The study incorporated a large number of variables for this purpose such as, gender wage gap, ratio of male to female participation rate, degree of gender discrimination based on skills and personality traits, sector wise placement and capital intensity, technological variations, fertility and comparative benefits and carried out a qualitative analysis of different researches from a period of 1990 to 2012, keeping the desired association in mind. This study concludes that technological advancement can minimize the gender inequality as decreased physical involvement benefits women in terms of productivity. Additionally, developed countries have lower gender gaps due to intense competition and numerous opportunities.

\section{THEORETICAL FRAMEWORK}

International trade is a process of buying and selling different sort of goods and services between different countries. The same process when repeated within country, it is called domestic trade. Global trade plays an essential role in the modern commercial economies as it benefits the producer all over the world to earn profits along with exposure, which they cannot get if they keep selling their products in local markets. Some other advantages of international trade include lower cost of production in one country as compared to other, cheap and abundant labor, enhanced competition, economies of scale, growth and development opportunities, specialized industries (the benefit of comparative advantage), abundance and shortage of natural resources and demand of certain products according to the taste of consumer (importance of international trade, 2005). However, if country's economic policy is based on protectionism, it will put various barriers on trade that includes tariff barriers, quotas, boycott, duties or other non-tariff barriers. These barriers act as an obstacle for the global trade. The reasons for putting barriers can be social, economic, political or environmental, but these barriers must be fair and transparent. Trade barriers can lead to inequalities in the society (Love \& Lattimore, 2009). On the other hand, trade liberalization can bring numerous benefits and it can boost trade economic growth. International trade play a significant role for the developing countries in many ways like; a) it can encourage development process by plummeting poverty through creating opportunities of investment, employment and enhancing the production bases via private sector growth; b) boosts competition by making the procedure of acquiring finance easy and aspiring, so that the 
procedures decrease input costs; c) supports innovation and diversification through exposure to modern markets and help in exchanging latest concepts of research and development investment, which is another important area under discussion; d) Domestic firms have the opportunities to expand due to limited trade barriers and easing export procedure and the relatively lower price of goods is beneficial for the consumers as supply is broadened; e) Trade not only creates job opportunities, greater income with better living standards but it also strengthens the peace and development process among various nations ultimately leading towards international harmony and stability, and; f) The removal of barriers is significant in reducing gender inequalities as it creates opportunities for women and encourage them to participate in the labor market. This happens because when the economy grows, it boosts economic activities and create various opportunities, which can play a significant role in empowering the women by making them self-sufficient.

\section{Some Theoretical Aspects of Gender Discrimination with Trade Liberalization}

Becker gave the theory of discrimination in his book titled "The Economics of Discrimination" in 1957. Originally, this theory was about the employers who have a certain taste of discrimination, especially with respect to hiring workers from minority groups (Author, 2003). This theory has been recently modified with respect to trade liberalization and gender equalities. Initially, it stated that the gender discrimination is a disease of market imperfection, especially with respect to hiring and paying standards in which preference is given to male over female. But the firms with such discrimination behavior tend to have higher costs and are driven out from the competition by the firms with no discrimination (Becker, 1971). Modification in this theory were carried out by the Black and Brained (2004), as in case of trade liberalization, the firms without prejudice and discriminating behavior will have the capability of supplying goods at a much lower rate as compared to the discriminating organizations. The domestic firms face the costs of discrimination and bias against female. With trade liberalization, these firm needs to make themselves competitive by lowering their costs, which can be done by overcoming the cost of discrimination. Hence, the products supply by international firms will be priced much lower than the products by the discriminating firms and will boosts the competition extensively for the discriminatory firms leading them towards bankruptcy. Therefore, it provides a channel which persuade the firms to employ female gender who have comparatively reduced wages with respect to male. It is also found that export industrialization is highly connected with enhanced levels of female participation in the developing economies (Ozay, 2011).

Cagatay (2005) theory is reliant on full employment, perfect competition and price adjustment which is quite unrealistic and are not followed in reality. The theory emphasis on four major points neglected by neoclassical theory. Primarily, they consider social associations to have an essential influence on economic growth and output (Cagatay,s 2005; Ozay, 2011). Secondly, the theory focus on reproductive aspect suggesting the recognition of unpaid work done by female like doing household work, and bearing and rearing children and to include this in the employment aspect. Thirdly, it is believed that factor prices are set by same society which led to differences in technology and production standards, therefore, it can explain the discrimination against women in various aspects, that is, the reasons behind the deprived group of female in society, economy, job opportunities, hiring standards, education and health (Elsonet al., 2007; Ozay, 2011). Lastly, it was stated that trade liberalization cannot be advantageous to all in equal manner, conversely, it will lead to more discrimination with respect to employment, salaries and decision making opportunities (Elson et al., 2007).

This can be comprehended in three ways, which are as follows. The policy impacts vary with gender, both socially and economically, as the roles played by male and female, that is, 
accessibly and authority towards resources are different. Female are more influenced by the adverse effects of trade liberalization as compared to male, which is mainly due to difference in education, training opportunities, wage inequalities, and power over resources. Trade liberalization can be beneficial or destructive for female depending upon the opportunities provided to them. On the other hand, gender imbalances could influence the trade policies as well. The reduction in gender gap, by enhancing the level of capital accumulation for female can lead towards higher economic performance. Whenever the emphasis is given to the education of female, it boosted the level of investment in the country. The country's growth is increased as a result of equality of education and job opportunities for female as economic growth and social equivalence go hand in hand. In addition, the trade policies must be formulated by keeping the gender factor in mind. In this way, the problems faced by male and female could be assessed, with solutions to capitalize on the opportunities for all, along with the inclusion of female in various dynamic sectors of the economy, so that the gender gap can be reduced and steps could be taken to empower the women (Women Watch, 2011)

This impact varies from country to country because of their specific patterns and ways to deal with global competition. With trade openness, the employment shares of these female who are either unskilled or have limited skills have been increases. But the poverty is not reduced especially for the families run by female because the employer tries to exploit the already gender differences. Although, through trade openness, the participation rate is increased, the economic condition and control over the financial resources is still low because of occupational inequality and wage gap. The huge complexities exited for female when it comes to labor mobility between sectors due to the cultural norms and lack of education/ skills. The income earned by female is also considered as secondary source of expenditures, instead of primary source. They are forced to do various tasks at home without any earning as well. Similarly, it is necessary to ensure the interest of female workers, by providing them opportunities to learn new skills along with better education and proper technical training. Recognizing, the importance of labor rights and taking every aspect to improve the working environment with necessary facilities. Another impact of trade openness is on small scale businesses run by female. These businesses are greatly affected, due to intense global competition despite the fact that they can be highly beneficial for the domestic economies in crisis times. Timely training opportunities must be provided in order to cope with competition (Women Watch, 2011). It is essential to encourage the appropriate and relevant contribution of female in trade consultation and discussion in addition to policy making and execution. To cooperate in exchanging the opinion with female that are involved in trade discussion, policy making and execution along with assisting the connections among the small scale business run by female and large multinational companies.

Seguino (2000) found that lower salaries for female have encouraged exports and investments by decreasing the product costs, giving foreign exchange for purchases and enhancing the level of productivity. The increased earnings from exports help in escalated economic growth, however, this enhanced production activity involves more male as compared to female and this is due to the fact that female tend to accept lower wages as persuaded by societal values and restrictions leading to lesser political instability and up surges investment but female participation remains low. The concluding hypothesis of the study by Wood and Wood and Ridao (1999) regarding the gender differentiated tendencies states that in the developing countries where gender gap in education exist, the hiring standards tend to discourage female's motivation to invest in enhancing their skills and creates more leaning opportunities for male. This is because of the fact that female is given those employment opportunities that ask for lesser skills, which reduces their chances to learn newer skills (Vijaya, 2003). 
Trade liberalization in Pakistan has a negative influence on women coming from the poor households as it up surged the workload, depreciated the skills and caused income inequalities, however, the impact is positive or neutral in rich households because of higher education and family business backgrounds. The study by Siddique (2009) determined the impact of trade liberalization from the aspects of both male and female in term of consumption and production. The unbiased revenue based trade liberalization guarantee a rise in participation of unskilled female working in labor market, however, the division of labor is still unfavorable for the female. The results of research explain that the discrimination in the labor market especially in female labor force participation and wage gap restricts the benefits of the revenue neutral trade openness. The increase in female wages boosts the female bargaining abilities. Also, when the trade liberalization is calculated with respect to the consumption of goods in the market, it tends to improve the welfare but it declines when the domestic chores and leisure are included in the calculation.

The female is working in huge numbers in the agricultural sector with lower incomes as compared to male, they also have lesser authority over the financial resources and access to markets, and lower education makes the overall productivity of female lesser. Due to the lack of skills, the opportunities are also taken by the male; therefore, the female cannot take any advantage of trade liberalization with all these restraints. To fully benefit from the trade liberalization, the women must be given access to markets. The restrictions on obtaining credit, education, skills must be decreased and the job created with the economic progress must involve more women-oriented positions so that the gender gap may reduce and women become more empowered (Korinek, 2005).

Numerous jobs have been created in the clothing and textile sectors for female, but they tend to hire the women with low skills, low education, and given low wages, which increase the employment rate but fail to reduce the wage gap. The jobs requirement of low or no skills evades the female from striving for improved working environment or more income. Korinek (2005) state that wage gap is prevalent because of the week bargaining skills of the women and they accept working in those companies that require lesser skills, education and are low paid. However, trade liberalization creates opportunities for female on the whole and given them power over resources and they spend it on education and health of their children.

Millennium Development Goals (MDG) initially given in the year 2000, emphasizes on the eradication of hunger and poverty giving everyone an equal employment opportunity, comprising both women and youth of the country as well. Its sub- target was added in 2005 and stated that decent work chance covers social protection, employment, rights at work place and social communication. Another millennium development goal aims at achieving gender equality and empowerment of women, which does not clearly refer to trade, but focuses on women empowerment by including those female who are working in non- agricultural sectors and analyzes the degree of wage employment of the female in formal sectors. Indirectly, the wage employment is connected with the trade as trade liberalization is considered to have involved women in the formal labor markets by creating jobs for them. The reduction of gender gap in terms of access to education is also related to trade in millennium development goals, as the educated female have more chances to gain full advantages of trade openness and participates in the labor markets by learning skills (Women Watch, 2011). The framework developed by assessing the association among the chosen variables is designed through figure 1. The figure explain the trade liberalization can play a significant role in reducing the gender gap along with enhanced women empowerment. However, the gender equality will be achieved if the female is given adequate opportunities of education, employment, and fair hiring regulations exists. Trade liberalization is also beneficial for economic growth as a whole. 


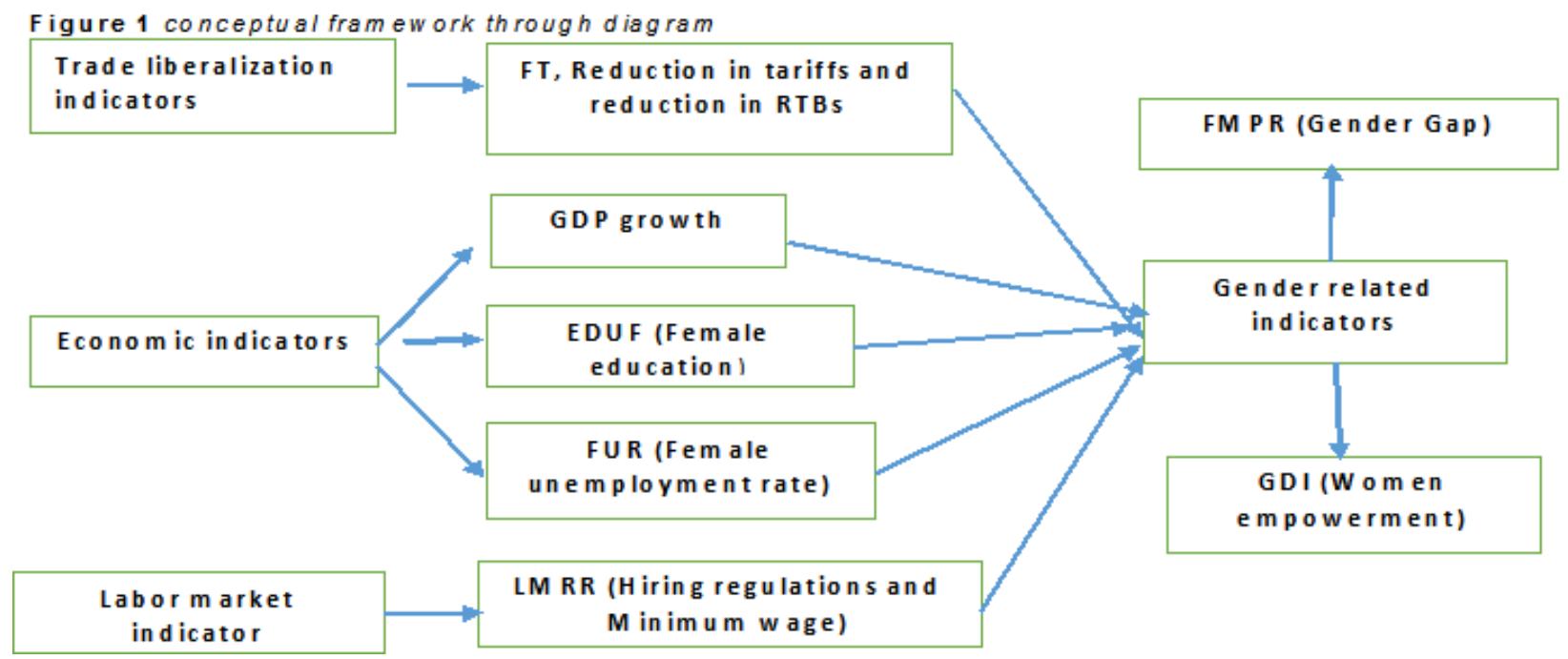

The time series cross section data is constructed to analyze the relationship of trade liberalization on gender gap and whether it leads to women empowerment or not? Gender gap and gender empowerment are measured through female to male participation rate (FMPR) and gender development index (GDI), respectively. The data of female to male participation rate (FMPR) is taken from world development indicators 2015 (WDI) published by world bank, whereas, the gender development index (GDI) data is taken from various issues of human development report (HDR) and United Nation Development Program (UNDP) reports. Female unemployment rate (FUR). Gross domestic product growth (GDPG), female education (EDUF) are also taken from the world development indicators 2015. The reduction in tariffs (TARIFF), reduction in regulatory trade barriers (RTB), freedom to trade (FT), and hiring regulations and minimum wage (LMRR) is gathered from the annual report of economic freedom of the world (2015) by Gwartney et al., 2015).

The sample initially consisted of all SAARC countries. However, due to unavailability of data, the sample was restricted to five SAARC countries (list of selected countries given in appendix A). The time period for this research is from 2000 to 2014. For empirically estimating the influence of trade liberalization on gender gap and its role in empowering the women, the general model equation is to be defined. In this study, four regression equations are formulated, where, gender development index (GDI) is used as a dependent variable in the first two equations to assess the effect of trade liberalization on the economic empowerment of the women. GDI covers three major disparities existing in the human development such as, education, health, and economic resources at hand. It is relative measure of women empowerment obtained by adjusting the human development index for gender disparities prevailing in human development achievements. On the other hand, the other two equations are designed to test the relationship of trade liberalization on the gender gap, reflected through FMPR. FMPR is the female to male participation rate in the labor market, and it measures the degree of female participation for the betterment of the society. This will be explained in detail.

The general econometric models are defined below.

$$
\text { GDI=f (Trade liberalization) }
$$

The relationship between trade liberalization with the gender development index (GDI), which is relative measure of women empowerment after adjusting the HDI for gender disparity can 
be stated in the following words; if the trade liberalization is increased, the GDI will go up (meaning lower gender inequality indirectly) and more women empowerment.

\section{Model 1}

$$
G D I_{i t}=\alpha_{0}+\alpha_{1} F T_{i t}+\alpha_{2} F U R_{i t}+\alpha_{3} E D U F_{i t}+\varepsilon_{i t}
$$

\section{Model 2}

$$
G D I_{i t}=\beta_{0}+\beta_{1} T A R I F F S_{i t}+\beta_{2} R T B_{i t}+\beta_{3} G D P G_{i t}+\beta_{4} F U R_{i t}+\varepsilon_{i t}
$$

The second functional form is given as:

$$
\mathrm{FMPR}=\mathrm{f} \text { (Trade liberalization) }
$$

The relationship between trade liberalization and female to male participation rate, which is a measure of the gender gap can be stated in the following words, when the trade liberalization goes up, gender disparities are reduced as more female are encouraged to take part in the economic development and progress, resulting in a rise in the female to male participation rate.

\section{Model 3}

$$
\boldsymbol{F M P R}_{i t}=\gamma_{0}+\gamma_{1} G D P G_{i t}+\gamma_{2} F T_{i t}+\gamma_{3} E D U F_{i t}+\gamma_{4} L M R R_{i t}+\varepsilon_{i t}
$$

\section{Model 4}

$F M P R_{i t}=\delta_{0}+\delta_{1} G D P G_{i t}+\delta_{2} T_{A R I F F S_{i t}}+\delta_{3} R T B_{i t}+\delta_{4} E D U F_{i t}+\delta_{5} L M R R_{i t}+\varepsilon_{i t}$

Where,

GDI = Gender development index

FMPRit = Female to male participation rate

TARIFFSit $=$ Reduction in tariffs

RTBit $=$ Reduction in regulatory trade barriers

GDPGit = Gross domestic product growth

FURit $=$ Female unemployment rate

FTit $=$ Freedom to trade

EDUFit $=$ Female education

LMRRit $=$ Hiring regulations and minimum wage

cit $=$ Error/residual term

The subscript ' $i$ ' and ' $t$ ' are both written alongside the variables because they indicate the inclusion of the characteristics of both cross sectional and time series data types. The subscripts ' $t$ ' represent the time series concerning the time period. The subscript ' $i$ ' represent the cross section consisting of 5 SAARC countries. Additionally, in the case equations, $\alpha 0, \beta 0$, $\gamma 0$, and $\delta 0$ represent the Equation $1,2,3$, and 4 respectively. An intercept is usually the constant term in the liner regression model. It is the mean value of the dependent variable, when all the independent variables' effects are considered equal to zero. Also, in Equation 1, there are $\alpha 1, \alpha 2$, and $\alpha 3$, which are the slope coefficients of the respective variables and shows the change in the dependent variable due to a change in the independent variables. The slopes of Equation 2 are $\beta 1, \beta 2, \beta 3$ and $\beta 4$. In equation $3, \gamma 1, \gamma 2, \gamma 3$ and $\gamma 4$ represent the slopes and the slopes of equation 4 are given as $\delta 1, \delta 2, \delta 3, \delta 4$ and $\delta 5$. In these regression equations, عit indicates the error term, which covers all other factors present in the environment and cannot be accounted for in the given equation. 


\section{RESULTS AND INTERPRETATION}

The following tables represents the regression results of the model 1 and 2. The Model 1 depicts the overall results of trade liberalization through freedom of trade (FT) on the gender empowerment measured through GDI. Whereas, the Model 2 shows the individual impact of the trade liberalization indicators such as reduction in tariffs (TARIFFS) and reduction in regulatory trade barriers (RTB) on gender empowerment.

Table 1 GDI as Dependent Variable

\begin{tabular}{|l|l|l|}
\hline Variables & Model 1 & Model 2 \\
\hline Tariffs & & $\begin{array}{l}0.1131^{* * *} \\
(6.89)\end{array}$ \\
\hline RTB & & $\begin{array}{l}0.0445^{* *} \\
(2.39)\end{array}$ \\
\hline GDPG & & 0.0046 \\
& & $0.77)$ \\
\hline FUR & -0.0015 & -0.0117 \\
& $(-0.27)$ & $(-2.99)$ \\
\hline FT & $0.1562^{* *}$ & \\
\hline EDUF & $(2.19)$ & \\
\hline C & $0.0019^{*}$ & \\
\hline Adjusted R-Square & $(1.70)$ & \\
\hline Number of observation & -0.4301 & -0.2323 \\
\hline Diagnostic test & $(0.265)$ & $(-1.58)$ \\
\hline & 0.5194 & 0.4402 \\
\hline & BREUSCH-PAGAN TEST & 59 \\
\hline & Prob: 0.5643 & BREUSCH-PAGAN TEST \\
& No heteroscedasticity & Prob: 0.6250 \\
& VIF: 2.76 & No heteroscedasticity \\
& No Multicollinearity & VIF: 1.30 \\
& REMSEY RESET TEST & No multicollinearity \\
\hline & Prob: 0.2541 & RAMSEY RESET TEST \\
& Model correctly specified & Prob: 0.1193 \\
& & Model correctly specified \\
\hline
\end{tabular}

\section{Note:}

$* * *, * *, * *$ represents level of significance at $1 \%, 5 \%$ and $10 \%$ respectively, t-statistics are shown within parentheses

In order to explore the relationship of trade liberalization on women empowerment, gender development index (GDI) is taken as a dependent variable which is defined as a relative measure of the gender empowerment and is formulated by adjusting the human development index (HDI) for gender disparity in education, health and economic/ financial resources. It is known as the gender sensitive expansion of HDI, but it is often mistaken to be a direct measure of gender gap, which is not true. This study has utilized GDI to measure gender empowerment since this index reflects the self-sufficiency in the three areas (health, education and financial resources). Therefore, higher GDI will reflect greater empowerment. GDI is usually combined with gender empowerment measure (GEM) to determine the levels of women empowerment. As the data of GEM was not available, only GDI was used in this research to avoid the problem of fewer observations. The relationship between trade liberalization is expected to be positive with the GDI or women empowerment, as when the economy emphasizes on free trade, the GDI goes up as the gender disparity is reduced, which in turn boosts women empowerment, making them self-sufficient. The women empowerment is the process of obtaining and utilizing the opportunities and self-sufficiency for the marginalized group of female (the group lacking self-sufficiency). When the women are empowered, they are self-sufficient in education, wages, and health. The independent variables include gross domestic product (GDP) growth, reduction in tariffs, and reduction in regularity trade barriers, female education, female 
unemployment rate and freedom to trade. The table 1 indicates the pooled OLS results obtained after running the regression analysis on these variables.

The impact of female unemployment rate is studied in both Model 1 and 2 . In model 1, the relationship among female unemployment rates with GDI is insignificant but negative, that is, higher the unemployment rate of female, lower the GDI, which refers to reduced degree of women empowerment in economy. The 1 percent increase in the unemployment rate will reduce the GDI by 0.0015 unit, that is, it will reduce the women empowerment. As according to the definition of GDI, the greater the gender disparity, lower is the GDI or women empowerment of the country. However, in Model 2, the association between female unemployment rates is highly negative and significant which suggests that as the unemployment rate goes up, the GDI of the country goes down, delaying the process of women empowerment as indirectly, gender differences are going up as a result of unemployment of female, since increased employment creates lesser opportunities aimed at empowering women. According to the current research outcomes, if the unemployment rate goes up by 1 percent, the GDI will go down by 0.0117 unit, which means a reduction in the women empowerment as the employment opportunities available for the female will be reduced.

The model 1 of the table 1 uses freedom of trade as an independent variable, which is a composite index and encompasses of four sub-indicators and is constructed to determine the overall impact of trade openness to the gender empowerment. It is very important measure of trade liberalization. The outcomes indicate that the freedom of trade is positively associated with GDI which means trade liberalization or flexibility in trade result in higher GDI of the country. The model 1 differs from the model 2 by taking the freedom of trade index, which is the overall rating of the trade openness. Model 2 incorporates the sub-components of the trade liberalization. If the freedom to trade ratings goes up by 1 unit, the GDI will go up by 0.1562 units. Hence, trade liberalization plays an important role in women empowerment. As mentioned above, freedom of trade is the composite indicator of trade liberalization and its sub-indicators include reduction in tariffs, non-tariff barriers, black market exchange rates and controls over the movement of goods and people from one location to another globally. Fontana and Wood (2000) added gender into a computable general equilibrium model of Zambia and Bangladesh in which they incorporated the male and female labor units individually and studied the framework with respect to household work and free-time with special emphasis on the trade liberalization. It is concluded that trade liberalization is comparatively more advantageous in Bangladesh than in Zambia due to higher female share of labor in export-oriented jobs. When the barriers of four different kinds are reduced together, the impact is huge, when the GDI goes up (indirectly reducing gender disparity), more opportunities are created to make the female self-sufficient, which boosts their presence in economic activities. Hence, GDI enhances the degree of women empowerment. More women become self-sufficient and empowered as a result of trade liberalization. Also, when the female share is enhanced in the import and export markets, only then the benefits of trade liberalization can be achieved to a greater extent.

Similar characteristics are shown by the female education variable which is positively related to GDI but the coefficient value is smaller which can be an indication of small contribution of the female education variable in the selected economies. However, the positive relationship indicates that higher levels of education lead to higher levels of GDI, meaning enhanced levels of gender empowerment. If the female education increases by 1 percent, the GDI or women empowerment will go up by 0.0019 unit. Education acts as the channel, which helps those women who have been stuck in the private spheres from a long time to shift towards the public sphere and declare themselves on an equal basis with men (Tarique \& Sultan, 2008). Moreover, 
when the trade liberalization is calculated with respect to the consumption of goods in the market, it tends to improve the welfare but it declines when domestic chores and leisure are included in the calculation. The education must be encouraged to evade the negative impact of trade openness on the poor households (Siddiqui, 2009). Thus, education can play a significant role. Additionally, Aguayo-Tellez (2012) concluded that if the women have educational opportunities, they will not only get reasonable jobs but also better salaries, reducing the wage gap. Therefore, it results in enhanced GDI, leading to an overall escalation in the process of women empowerment. When the female of any country are educated and skilled, they can not only be self-sufficient for their own benefit but they will also be very helpful for the development and progress of the country. The female when educated can teach their future generations as well in a better way and use advanced of hygiene and living standards which enhances the overall well-being of any household. Hence the empowered women play a key role in any economy.

Moreover, in Model 2 of Table 5.1 relationship between reduction in tariffs and GDI, which is relative measure of gender empowerment, after adjusting for gender disparity in human development achievements is not only highly significant but also positive as well. If the trade liberalization in terms of tariffs ratings goes up (that is, tariff barriers are reduced) by 1 unit, then the GDI will go up by 0.1131 unit, meaning creating women empowerment. Because the tariffs are the taxes that are levied on the trading of good and services, and when tariffs are higher, the import and export become expensive which causes the tariffs ratings to go down. It leads to a reduction in global trade as traders will be discouraged due to larger costs (Riaz, 2014)

Therefore, if the advantages of trade liberalization are to be fully utilized, there must be removal of tariff barriers which in turn increases the GDI, resulting in the women empowerment in an economy, when the barriers are lesser, the inequality is also lower indirectly, creating opportunities for female and they are more willing to enter the labor market and add to the economic growth of the country. The overall betterment of the female gender occurs. Lower barriers also increase the competition and higher competition leads to empowerment of female who are ready to face the challenges and are beneficial for economy, since they get empowered to utilize the benefits from the opportunities created through the trade liberalization. Schultz (2006) explained that trade restrictions in the form of tariffs, quotas or foreign exchange rates curbs the opportunities available for women regarding health or education, hence, disturbing the process of gender empowerment or the course of marginalizing those women who lack self-sufficiency.

The behavior of the regulatory trade barriers is similar to that of the tariff barriers. The present study shows that the higher ratings of regulatory trade barriers lead to an increase in the women empowerment or GDI which indirectly means a reduction in gender disparity. Here, the coefficient value of reduction in RTB is 0.0445 and it is significant, which means, if the regulatory trade barrier ratings are increased by 1 unit, the relative measure of women empowerment, that is GDI will go up by 0.0445 unit. The removal of such barriers can pave ways for useful opportunities for female and the empowerment of women in labor market enhances economic growth. Also, when the company is prospering, the inclusion of female is highly important as they can cope with the challenges in better ways (Schultz, 2006; Riaz, 2014; Mehmood et al., 2015). The result of the current study is in line with the past literature. Pramanik (2010) concluded in the research that trade liberalization or openness has contributed a lot in improving the health standards for the women work in Bangladesh. Changing trade reforms such as decrease in the tariff bands and tariff rates, allowance of tax breaks, duty drawbacks and removal of non-tariff barriers resulted in the augmentation of 
growth and trade both. Trade openness and women empowerment have a positive association in many studies (Ahmad, 2008). Plenty of opportunities have been created for women to get paid work and jobs along with a significant role in undertaking household decisions. The outcomes of present research are in line with the above conclusions.

Additionally, the connection of growth in gross domestic product and GDI is positive which means that an increase in the economic growth causes a rise in the GDI of the country which tends to enhance the level of women empowerment in any economy, but this impact is not significant. If the GDP growth goes up by 1 percent, the GDI will go up by 0.0046 unit or there will be an increase in the women empowerment by 0.0046 unit. This effect might be trivial because the countries used in the sample for this study are still in the development phase and the advantages of the trade liberalization are not fully achieved. Growing economies always need empowered female for their progress so that they can use their skills and abilities to deal with the challenges as the female can add to the well-being of the society. However, the women empowerment is achieved when the female are given equal access to agricultural, farming, land and financial resources, when they are given proper access to legal rights, to education and employment opportunities without any discrimination (Mehra, 2015). Although the SAARC countries on their way to empower women, but the majority of female are still working in low paid sector with limited access to education. Therefore, the impact of GDP on gender empowerment is insignificant and trivial. Furthermore, the model 1 and 2 in table 1 also depict the outcomes from the diagnostic tests and it is evident that the pooled OLS technique applied on the chosen variables is free of issues like heteroscedasticity, multi co linearity and model misspecification.

The following tables represent the regression results of the Models 3 and 4. The model 3 depicts the overall result of trade liberalization through freedom of trade (FT) on the gender gap measured by FMPR, whereas, the model 4 shows the individual impact of the trade liberalization indicators such as reduction in tariffs (TARIFFS) and reduction in regulatory trade barriers (RTB) on gender gap. 
Table 2 FMPR as Dependent Variable

\begin{tabular}{|c|c|c|}
\hline Variables & Model 3 & Model 4 \\
\hline GDPG & $\begin{array}{l}0.0181 \\
(0.70)\end{array}$ & $0.0363 *(1089)$ \\
\hline TARIFFS & & $\begin{array}{l}-0.1362^{* *} \\
(-2.70)\end{array}$ \\
\hline RTB & & $\begin{array}{l}-0.3740^{* * *} \\
(-5.26)\end{array}$ \\
\hline EDFU & $\begin{array}{l}0.0194^{* * *} \\
(4.58)\end{array}$ & $\begin{array}{l}0.0081^{* *} \\
(2.64)\end{array}$ \\
\hline LMRR & $\begin{array}{l}-0.0425 \\
(-1.60)\end{array}$ & $\begin{array}{l}-0.0117 \\
(-0.45) \\
\end{array}$ \\
\hline FT & $\begin{array}{l}-0.8524^{* * *} \\
(-4.11)\end{array}$ & \\
\hline $\mathrm{C}$ & $\begin{array}{l}8.2439^{* * *} \\
(7.28)\end{array}$ & $\begin{array}{l}6.2874^{* * *} \\
(13.52)\end{array}$ \\
\hline ADJUSTED R Squared & 0.3436 & 0.6949 \\
\hline Number Of Observations & 38 & 36 \\
\hline Diagnostic Tests & $\begin{array}{l}\text { BREUSCH-PAGAN TEST } \\
\text { Prob.: } 0.5749 \\
\text { No Heteroscedasticity } \\
\quad \text { VIF: } 2.49 \\
\text { No multicollinearity } \\
\text { RAMSEY RESET TEST } \\
\text { Prob.: } 0.4704 \\
\text { Model Correctly Specified } \\
\text { Woodridge Test } \\
\text { Prob.: } 0.2109 \\
\text { No Autocorrelation } \\
\end{array}$ & $\begin{array}{l}\text { BREUSCH-PAGAN TEST } \\
\text { Prob.: } 0.7712 \\
\text { No Heteroscedasticity } \\
\text { VIF: } 2.83 \\
\text { No Multicollinearity } \\
\text { RAMSEY RESET TEST } \\
\text { Prob.:0.4339 } \\
\text { Model Correctly specified } \\
\text { Woodridge Test } \\
\text { Prob.: } 0.1609 \\
\text { No Autocorrelation }\end{array}$ \\
\hline
\end{tabular}

\section{Note:}

$* * *, * *$, represents level of significance at $1 \%, 5 \%$ and $10 \%$ respectively, t-statistic are shown within parentheses

In order to explore the relationship of trade liberalization on gender gap in SAARC countries, the third and fourth models incorporated female to male participation rate to determine gender gap prevailing in labor market. Since, FMPR is the ratio of female to male; hence, it reflects the gender gap, particularly in the labor market. Female to male participation rate (FMPR) is a dependent variable in this equation, whereas, the independent variables are reduction in tariffs, gross domestic product (GDP) growth, reduction in regulatory trade barriers, freedom to trade, education of female and hiring regulations \& minimum wages (LMRR). LMRR is taken because this research focuses on the involvement of female in the economy which is measured through their participation in the labor market relative to male; flexible hiring regulation and minimum wage standards will help to examine whether it affects the participation of female in the labor markets relative to the male. The table 2 represents the pooled OLS results by incorporating the aforementioned variables into the regression equation.

In model 3 of table 2, the outcomes show significant associations among the variables which can be regarded as the result of including the freedom to trade variable which is composite indicator of trade liberalization and cover other aspects as well, in addition to the reduction in tariffs and reduction in RTBs. In this model, GDP growth rate is positively linked to the female to male participation rate, but it is insignificant. If the gross domestic product is increased by 1 percent, the gender gap will go down by 0.0181 percent, which causes the female to male participation rate to go up by an equivalent 0.0181 percent as lower gender gap refers to higher female to male participation rate. According to Goldin (1995), female labor participation rate initially declines with the economic growth, but as the time passes, the relationship 
between GDP and female to male participation rate becomes positive and rises. This refer to the concept of U-hypothesis, which endorses that initially the relationship is negative but as the economy grows, it needs the inclusion of female labor, which in turn boosts the female to male participation rates and reduces the gender gap. U-hypothesis states that before the economies are developed, a large number of female work in the agriculture sector, but when the economies start developing, their emphasis is shifted from agriculture to market and industry oriented sectors which initially decrease the female participation in the labor market. But in the process of technological development, there comes a point where the economy needs female involvement and from that point, the female to male participation rate starts going up, hence, the U-shape (Goldin, 1995; Cakir, 2008). As a result of increased female to male participation rate, the gender gap is decreased. However, in this study, the sample of countries is at their initial stages of the U-hypothesis, due to which the gender gap is not being reduced as a result of trade liberalization. The opportunities created are still more favorable to male, instead of the female. Also, the impact of higher economic growth will only be beneficial in reducing gender gap, if the women are given opportunities to the economic activities, along within the power to bargain in family and work related decisions (direct way) and by removing the restrictions in the labor market that arise due to discrimination by the employers. If the cost of discrimination is increased, then it might be possible that government and firms will adopt more gender equitable policies (Kabeer \& Natali, 2013). The SAARC countries are still at the development phase, and women are still working in low paid or unpaid and discrimination work place, due to which the impact of GDP on gender gap is insignificant.

Freedom to trade is a composite indicator of trade liberalization, and it shows a highly significant and negative association with female to male participation rate, similar to the behavior shown by reduction in tariffs and reduction in regulatory trade barriers. Usually, it is expected that when the freedom of trade goes up (barriers of all sorts are reduced), the female to male participation rate will go up and gender gap will be reduced, making it a positive association between freedom to trade and FMPR.

However, in this case, the outcomes are differed. Therefore, in this study, when the freedom of trade rating goes up, it indicates the removal of trade barriers of all kinds along with the controls on the movement of goods and people and the creation of new avenues of work opportunities. However, it is not reducing the gender gap, or boosting the female to male participation rate because the opportunities which are created are biased towards the male and female are still working in the low paid sectors with their limited skills. The coefficient value of freedom to trade is 0.8524 which includes the impact of reduction in tariffs, NTB, black market exchange rates and controls on the movement of goods and people. If all of these are reduced, there will be a huge impact on the female to male participation rate or when all the barriers are reduced, the rating will go up, resulting in a huge reduction in the female to male participation rate. It indicates that if the freedom to trade as a whole is reduced by 1 unit, the female to male participation rate will go down by 0.8524 percent or the gender gap will increase by an equivalent 0.8524 percent.

The variable to female education is incorporated in both the Models 3 and 4. The association shown by female education towards female to male participation rate is identical to that of Model 3 and 4 . The coefficient value is 0.0194 which is higher than the coefficient value of female education in Models 4 , which is 0.0081 . If the female education is increased by 1 percent, the female of male participation rate is enhanced by 0.0194 percent. The increased education for female creates economic opportunities for them. The increased education polishes the skills and confidence which in turn encourages the female to join the labor force and contribute in the economic development leading to a satisfactory reduction in the gender 
gap. Fofana et al., (2005) explored the impact of trade openness in Nepalese economy and suggested that complete removal of all sorts of tariffs and controls on the movement of people and goods can be highly beneficial for female boosting their salaries but reducing the leisure time. Trade reforms increase the leisure time of male. On the other hand, despite the fact that, through trade openness, the participation rate is increased, the economic condition and control over the financial resources is still low because of occupational inequality and wage gap. The huge complexities exist for female when it comes to labor mobility between sectors due to the cultural norms and lack of education/ skills (Women Watch, 2011). In Model 4, the female education is significantly and positively associated with the female to male participation rate having a coefficient value of 0.0081 , meaning, as the female attain higher education, they take an active part in the labor market which reduces the gender gap and the economic growth is escalated. If the female education goes up by 1 percent, the participation rate of female in the labor market goes up by 0.0081 percent or the gender gap is reduced by 0.0081 percent. As suggested by Verick (2014), education plays a key role in labor force participation, usually the female have limited access to education as compared to men, but when they attain higher education and are given employment opportunities, female tend to participate in the economy in greater numbers. The study further states that female with lesser education are still working in informal low wage jobs, but once the level of education rises, they are willing to join the job market if appropriate opportunities arise. If the female is educated and aware, they know their abilities and do not compromise on anything lesser than what they deserve according to their skills and education, which is a great step towards gender equality.

LMRR (hiring regulations and minimum wage standards) is also used in both the Models 3 and 4. The relationship among hiring regulation and minimum wage is negative and insignificant in both of the Models 3 and 4. If the hiring regulations ratings are increased by 1 unit, which means the regulations are made flexible, the female to male participation rate is curbed by 0.0425 percent or if there is an increase in the hiring regulation and minimum wage rating, the gender gap will go up by 0.0425 percent which is contrary to the idea that flexible regulations will boost the female to male participation rate. This is because of the flexibility in the regulations which favorable for the male and the female is still facing huge discrimination during the hiring process. Ederingto et al., (2009) examined if increased competition will decrease the discrimination as suggested by Becker's theory. As almost all the sectors are indulged in discrimination while hiring and giving wages especially in case of female. It was found that the firms with discriminatory practices have to face higher costs, which restricts their profits and shifts them to other companies with no discrimination. The competition pressurizes the discriminatory firms to exit the market and capital investments are done with the other firms. The higher levels of trade openness lead to boosting the competition as well, which in turn causes the domestic firms to ease their regulations which attract the female to join them on reasonable wages and as a result of this, the gender gap is reduced. But in this study, the gender gap is not reduced and female to male participation rate goes down which can be observed from the labor force surveys of the SAARC countries, that female is still working in low paid sectors as compared to the male who are given more opportunities to learn skills, attain higher education and are favored by the employers while getting jobs. Moreover, the similar results are shown in the Model 4. The hiring regulations and minimum wage affects negatively, because whenever the regulations are flexible, the rating value assigned to this variable goes up, and as a result the involvement of women and the participation rate goes down and the regulations are more male oriented and favor the male. If the hiring regulations ratings go up by 1.00 Unit, the female participation in the labor market is reduced by 0.0117 percent or the gender gap is increased by 0.0117 percent. Korinek (2005) explained that female tend to face discrimination during hiring procedures, which discourages and limits their chances to participate in the labor market. Also, wage discrimination can be 
seen in all the sectors of the economy. As the flexible regulations favor the male, it reduces the female to male participation rate which upsurges the gender gap. The employers tend to discriminate while hiring due to gender biases which is unfavorable for female.

In Model 4 of Table 2, the relationship between GDP growth and female to male participation rate is positive and significant which means growth in the economy leads to the creation of opportunities for female which in turn encourages the women to come out of their homes to work and boost their participation level in the labor market. So, when the GDP growth goes up, the female to male participation rate also increase. If the gross domestic product goes up by percent, the female to male participation rate will go up by 0.0363 percent. As suggested by Mehmood et al., (2015) the increase in gross domestic product enhances the level of female to male participation rate because as the economy progress, there is new opportunity for work and challenges along with this boosted labor demand will be met by educated, competitive and skilled female. Another motivation for female to join labor force is that, as the economy grows, there is increase in inflation as well. It persuades the female alongside the male members of the family to work so that they can earn extra income to fulfill the expenditures which lead to a major reduction in the gender discrimination prevalent in the society and economy.

However, the reduction in tariffs shows a negative but significant association. In this study, trades indicators are described through rating, higher rating mean lower tariff barrier and higher trade liberalization. In this way, the negative association between reduction in tariffs and FMPR, so it suggests that higher trader liberalization is not playing the role in reducing the gender gap. As the results in the previous models suggest that trade liberalization empowers women but the Model 3 and 4 indicates that it does not help in reducing the gender gap by increasing the participation of female in economy. The reason could be that the opportunities created as a result of trade liberalization are more male oriented as compared to being female oriented. This may also be dependent upon the type of industries and the nature of countries from which data is taken. As according to the labor force surveys in selected countries, the female is still working in the low paid sectors which require lesser skills; therefore, the new opportunities are more inclined towards the male instead of female. If the tariff ratings are increased by 1 unit, the female to male participation rate goes down by 0.1362 percent, which means the job opportunities created for male are 0.1362 percent more than those created for the female.

Furthermore, the reduction in regulatory trade barriers represent the similar behavior as that of reduction tariff, a significant but negative relation with female to male participation rate. If the RTB rating goes up by 1 unit, the female to male participation rate goes down by 0.3740 percent indicating that the gender gap is not reduced. As explained before, regulatory trade barrier include both tariff and non- tariff barrier, which means the impact of regulatory trades barriers is expected to be higher, it is because higher tariff on travel, custom, licensing, the more it discourages the traders (Riaz, 2014). The male is given more opportunities of education, learning new skills and for adapting to the latest trends and development in labor market. Model 3 and 4 of the table 2 also show outcome from the diagnostic tests and it is evident that the pooled OLS technique applied on the chosen variable is free of issues like heteroscedasticity, multicollinearity, auto correlation and model misspecification.

\section{CONCLUSION AND POLICY IMPLICATION}

This research is conducted with objectives of exploring the relationship of trade liberalization on gender gap and women empowerment individually along with the special emphasis on the role of trade indicators like reduction in tariffs and reduction in regulatory trade barriers in reducing gender gap and enhancing the level of women empowerment. A sample of five SAARC 
countries is selected and data on the chosen variables is gathered for a time period of 2000 to 2014. The chosen variables included two independent variables; female to male participation rate (FMPR) to measure the gender gap and gender development index (GDI) as a relative measure of women empowerment after adjusting the human development index for gender disparity. The indicators of trade liberalization include reduction in tariffs (TARIFFS), reduction in the regulatory trade barriers (RTB), and freedom of trade (FT) which is a composite index as the independent variables along with few control variables comprising female education (EDUF), gross domestic product growth (GDPG), female unemployment rate (FUR) and hiring regulations \& minimum wage (LMRR). The economic technique of pooled ordinary least square (OLS) is applied on the four regression equations which are formulated to determine the above mentioned association and impact.

The relationship among female unemployment rates with GDI in Model 1 is insignificant but negative, that is, higher the unemployment rate of female, lower the GDI which refers to reduced women empowerment in the economy. The Model 1 uses freedom of trade as an independent variable, which is a composite index and comprises of four sub-indicators. The outcomes indicate that the freedom of trade is positively associated with GDI which means that the trade liberalization or flexibility in trade results in higher GDI of the country. If the freedom to trade ratings or trade openness goes up by 1 unit, the GDI will go up by 0.1562 unit. When the barriers of four different kinds are reduced altogether, the impact is huge, more employment opportunities are created, and female are given trainings and education which boost their presence in the labor market. It empowers them and makes them self- sufficient in education, health and financial resources. Also, when the female share is enhanced in the imports and exports markets, only then the benefits of trade liberalization can be achieved to a greater extent. Similar characteristics are shown by the female education variable which is positively related to GDI but the coefficient value is smaller which can be an indication of small contribution of female education variable in the selected economies. However, the positive relationship indicates that higher level of education leads to higher level of GDI, meaning enhanced degree of gender empowerment. Education acts as the conduit which helps those women who have been stuck in the private spheres from a long time to shift towards the public sphere and declare themselves on an equal basis with men (Tarique \& Sultan, 2008). The female when educated can teach their future generation as well in a better way and use advanced methods of hygiene and living standards which enhances the overall well- being of any household.

In Model 2, the association between reduction in tariffs and GDI is not only highly significant but it is positive as well. If the trade liberalization in terms of tariffs ratings goes up (barriers are reduced) by 1 unit, then the GDI will go up by 0.1131 unit meaning an increase in the women empowerment (higher GDI means greater women empowerment). If the advantages of trade liberalization are to be fully utilized, then the tariffs must be reduced which increase the trade liberalization and as a result, women are empowered. When the barriers are lesser, more opportunities for female are created and they are more willing to enter the labor markets and work to add into the economic growth of country. Lower barrier or higher trade openness increases the competition and higher competition leads to empowerment of female who are ready to face the challenges and are beneficial for the economy. Women empowerment is the process of obtaining and utilizing the opportunities for the marginalized group of female (the group lacking self-sufficiency). Similar is the case with the reduction in regulatory trade barriers as literature and theory both suggests that higher RTB ratings or lower trade barriers (tariffs and non- tariffs) lead to an increase in GDI meaning more women empowerment. Here the coefficient value of reduction in RTB is 0.0445 and it is significant, which means, if the regulatory trade barrier ratings are increased by 1 unit, the GDI goes up by 0.0445 unit. The 
connection of growth in gross domestic product and GDI is insignificant but positive which means that an increase in economic growth causes a rise in the GDI of the country which indirectly reduces the gender disparity and directly enhances the level of women empowerment. Growing economies always need empowered and aware female so that they can use their skills and abilities to deal with the challenges and add to the well-being of the society. The association between female unemployment rates is highly negative and significant which suggests that the unemployment rate goes up, the GDI of the country goes down which refers to a reduction in the women empowerment.

The outcomes of Model 3 show that if the gross domestic product is increased by 1 percent, the gender gap will go down by 0.0181 percent, which causes the female to male participation rate. According to Goldin (1995), female labor participation rate initially declines with the economic growth, but as time passes, the relationship between GDP and female to male participation rate becomes positive and rises. This refer to the concept of U- hypothesis, which endorses that initially the relationship is negative but as the economy grows, it needs the inclusion of female labor, which in turn boosts the female to male participation rates and reduces the gender gap prevalent in the economy. Freedom to trade is a composite indicator of trade liberalization, and it shows a highly significant and inverse association with the female to male participation rate, indicating that when the freedom to trade rating goes up, it means that the trade barriers of all kinds along with the controls on the movement of goods and people are removed, new avenues of work opportunities are created but the female to male participation rate is decreased by increasing the gender gap as the employment opportunities created for female are very lower than those created for male. Also, the coefficient value of freedom to trade is 0.8524 which includes the impact of reduction in tariffs, NTBs, black market exchange rates and controls on the movement of goods and people. The association shown by female education towards female to male participation rate is identical to that in Model 4. The coefficient value is 0.0194 which is higher than the coefficient value of female education in Model 4, which is 0.0081. If the female education increased by 1 percent, the female as compare to male participation rate is enhanced by 0.0194 percent or the gender gap is reduced by 0.0194 percent. The increase is attributed to the addition of FT variables, and it can be stated that when there is freedom of trade, the educational opportunities also increase. It becomes relatively easier to visit other countries as well, which enhances the quality of education and polishes the skills and confidence which in turn encourages the female to join the labor force and contribute in the economic development. The relationship among hiring regulation and minimum wage in Model 3 is negative and insignificant as in case of Model 4, confirming the fact the tighter regulations act as an obstacle in women participation levels in the labor market, hence, widening the gender gap. Or it can be explained as, not only the tighter regulations curb women participation, but even the flexible regulations do the same as the lenient hiring regulations mostly favors the male and female still face huge discrimination during the hiring processes, which increases the gender gap.

In Model 4, the relationship between GDP growth and female to male participation rate is positive and significant which means growth in the economy encourages the participation of female in the labor market which reduces the gender gap. Another motivation for female to join the labor force is that as the economy grows, there is an increase in the inflation as well. It persuades the female alongside the male members of the family to work so that they can earn extra income to fulfil the expenditures, however, the reduction in tariffs show a negative but significant association. As the tariffs are defined by ratings, and higher ratings refer to lower tariff barriers, it suggests that as the tariff ratings are increased, the tax imposed on the trade of goods and services will be decreased making the products inexpensive. The reduction in tariffs and export duties or an increase in tariff ratings lead to positive industry growth but it is 
not reducing the gender gap, as the female to male participation rate is decreased. As the job opportunities which are created after trade liberalization are more male oriented instead of female oriented. Furthermore, reduction in regulatory trade barriers represents the similar behavior as that of reduction in tariffs, a significant but negative relation with the participation rate. Increasing the RTB rating is usually expected to increase in the female to male participation rate but it is not happening in this study. The increased RTB ratings is decreasing the FMPR as the male are getting more opportunities as compared to female and gender gap is not reducing. Female education is significantly and positively associated with the female to male participation rate having a coefficient value of 0.0081 , meaning, as the female attain higher education, they may take active part in the labor market, the gender gap is decreased and the economy growth is escalated. If the female are educated and aware, they know their abilities and do not compromise on anything less than what they deserve according to their skills and education, which is a greater step towards gender equality. Hiring regulations and minimum wage affects negatively, because whenever the regulations are flexible, the ratings go up, and they restrict the participation rate of women increasing the gender gap in the economy. Based on outcomes from the regression analysis, this research devise the following policy recommendations so that the SAARC countries can fully utilize the benefits of trade liberalization in reducing the gender inequality and take measures for augmenting the level of women empowerment; Every country must reduce the trade barriers (tariffs and non- tariffs) as it will encourage the traders for import and export which in turn enhances the competition in the domestic industries. The intense competition asks for a large number of workers especially the skilled ones, and women are expected to carry out the tasks in a better way if they are given an equal chance to prove themselves.

Special emphasis must be given to the education of female as compared to the present, because education can actually transform and polish the skills and abilities of female which helps in boosting their role and contribution in the economy. It will be advantageous in fully utilizing the benefits from trade liberalization; both domestically and internationally. Female education will not only decrease the gender gap but also improve the level of women involvement in the country. Work opportunities for female should be created and the women must be encouraged to take part in the development of the economy. It is essential for the marginalized group of female to become self- sufficient. Importance must be given for trainings and skills development of female including the business and leadership skills, because if the female is unskilled then the gender inequality will prevail even if there are enough opportunities for them. Usually the trainings improve the skills and abilities of men and they utilize the work opportunities and women continue to work in low paid sectors with limited chances to grow and add to the economic growth. The organizations and the industrial sector must bring reforms in their hiring procedures as both female and male should be given equal chance to prove their capabilities and if either gender is suitable for the required jobs, he or she must be hired without any discrimination. Educated and skilled female are more aware and it helps them in understanding what they deserve according to their abilities and they will not compromise on less. Numerous studies endorse this fact that companies with discriminatory hiring practices are thrown out of the labor market sooner or later.

\section{References}

Aguayo-Tellee, E. (2012). The impact of trade liberalization policies and FDI on gender inequalities: A literature review. World development report 2012.

Aguayo-Tellee, E. Airola, J. Juhn, C. and Villegas-Sanchez, C. (2010). Did trade liberalization help women? The case of Mexico in the 1990's (No. w16195). National Bureau of Economic Research.

Ahmad, N. and Hyder, K. (2006). Gender inequality and trade liberalization: A Case Study of Pakistan (No. 16252).

University Library of Munich, Germany. 
Ahmad, S. (2008). Trade and Gender: Quantitative Approaches, United Nations Conference on Trade and Development (UNCTAD). India, Retrieved from http://artnet.unescap.org/tid/artnet/mtg/cbcam_d1s4.pdf

Atieno, R. (2006). Female Participation in the labor market: the case of the informal sector in Kenya (No. RP_157). African Economic Research Consortium.

Author, D. (2003). Lecture Note: The Economics of Discrimination- Theory. Graduate Labor Economics I, Massachusetts Institute of Technology, Cambridge, 1-18.

Beck, N. (2004). Longitudinal (panel and time series cross- section) data. Unpublished manuscript, Retrieved from http//www.nyu.edu/gsas/dept/politics/faculty/beck/beck_home.html

Becker, G. S. (1971). The Economics of Discrimination. University of Chicago Press Economics Books.

Benefits of free trade. (2013). Retrieved from http://www.economicshelp.org/trade/benefits_free_trade/

Berik, G. Rodgers, Y. V. D. M. and Seguino, S. (2009). Feminist economics of inequality, development, and growth. Feminist Economics, 15(3), 1-33.

Black, S. E. and Brainerd, E. (2004). Importing equality? The impact of globalization on gender discrimination. Industrial \& Labor Relations Review, 57(4), 540-559.

Black, S. E. and Brainerd, E. (2002). Importing Equality? The impact of Globalization on Gender Discrimination (No. 9110). National Bureau of Economics Research, Inc.

Bolaky, B. and Freund, C. L. (2004). Trade, regulations, and growth. World Bank Policy Research Working Paper, (3255).

Burgoon, B. and Hiscox, M. J. (2008). The Gender Divide over International Trade: Why do men and women have different views about openness to the world economy? Cambridge, MA: Harvard University.

Cagatay, N. (2005). Gender inequalities and international trade: a theoretical reconsideration. Department of Economics, University of Utah, United States Consultado el, 2.

Cakir, O. (2008). The Relationship between Economic Development and Female Labor Force Participation within the Framework of U-Shaped hypothesis: Evidence from Turkey. Department of Economics, School of Economics and Management, Lund University, Sweden.

Chakraborty, T. (2012). Impact of Industrialization on Relative Female Survival: Evidence from Trade Policies (No. 6647). Institute for the Study of Labor (IZA).

Contessi, S. De Nicola, F. and Li, L. (2012). International trade, Female Labor, and entrepreneurship in MENA countries. FBR of St. Louis Working Paper No.053C.

Dollar, D. and Gatti, R. (1999). Gender in equality, income, and growth: are good times good for women? (Vol. 1). Washington, DC: Development Research Group. The World Bank.

Ederington, J. Minier, J. and Troske, K. (2009). Where the Girls Are: Trade and Labor Market Segregation in Colombia (No. 4131). Institute for the study of Labor (IZA).

EL-Hamidi, F. (2008). Trade Liberalization, Gender Segregation, and Wage Discrimination: Evidence from Egypt. Economic Research Forum Working Papers (No. 414).

Elson, D. and Evers, B. (1996a). Gender aware country economic reports: concepts and sources. GENECON Unit Working Paper 1, University of Manchester.

Elson, D. Grown, C. and Cagatay, N. (2007). Mainstream, heterodox, and feminist trade theory. The Feminist Economics of Trade, 5, 33.

Essays, U. K. (2013). Advantages and Disadvantages of Free Trade Economics Essay. Retrieved from http://www.ukessays.com/essays/economics/advantages-and-disadvantages-of-free-trade-economicsessay.php?cref $=1$

Fofana, I. Cockburn, J. and Decaluwe, B. (2005). Developing country Superwomen: Impacts of Trade Liberalization on Female Market and Domestic Work. Cahier de recherché/ Working Paper, 5, 19.

Fontana, M. (2003). The gender effects of trade liberalization in developing countries: a review of literature. Discussion Papers in Economics, (101).

Fontana, M. and Wood, A. (2000). Modeling the Effects of Trade on Women, at work and at Home. World Development, 28(7), 1173-1190. 
Fontana, M. Joekes, S. P. and Masika, R. (1998). Global trade expansion and liberalization: gender issues and impacts. Brightone: Institute of Development Studies.

Gaddis, I. and Pieters, J. (2012). Trade Liberalization and Female Labor Force Participation: Evidence from Brazil (No. 6809). Institute for the Study of Labor (IZA).

Galor, O. and Weil, D. N. (1996). The Gender Gap, Fertility, and Growth. American Economic Review, 86(3), $374-87$.

Goldin, C. (1995). The U-Shaped Female Labor Force Function in Economic Development and Economic History. Investment in Women's Human Capital, 61.

Goldin, C. and Katz, L. (2008). Gender Differences in Careers, Education and Games. American Economic Review, 98(2), 363-69.

Gwartney, J. Lawson, R. and Norton, S. (2015). Economic freedom of the world 2015 annual report. The Fraser Institute.

Hill, M.A. and King, E. (1995). Women's education and economic well- being. Feminist Economics, 1(2), 21-46.

Importance of International Trade. (2005). http://www.moneyinstructor.com/doc/internationaltrade.asp

Juhn, C. Ujhelyi, G. and Villegas-Sanchez, C. (2013). Trade liberalization and gender inequality. The American Economic Review, 103(3), 269-273.

Kabeer, N. and Natali, L. (2013). Gender Equality and Economic Growth: Is there a Win- Win? IDS Working Papers, 2013(417), 1-58.

Klasen, S. (1999). Does gender inequality reduce growth and development: Evidence from cross- country regressions (pp. 1- 12). World Bank, Development Research Group, Poverty Reduction and Economic Management Network.

Klasen, S. and Lamanna, F. (2009). The impact of gender inequality in education and employment on economic growth: new evidence for a panel of countries. Feminist economics, 15(3), 91-132.

Korinek, J. (2005). Trade and Gender: Issues and interactions (No. 24). OECD Publishing.

Lagerlof, N. P. (2003). Gender equality and long run growth. Journal of Economic Growth, 8(4), 403-426.

Love, P. and Lattimore, R. (2009). Protectionism? Tariffs and other barriers to trade. International Trade: Free, Fair and Open, 54-57.

Maqsood, F. (2014). Impact of Globalization on Female Labor Force Participation in the SAARC Region. Pakistan Journal of Social Sciences (PJSS), 34(2), 523-533.

Mehmood, B. Ahmad, S. and Imran, M. (2015). What drives female labor force participation in Muslim countries? A generalized method of moments inference. Pakistan Journal of Commerce and Social Sciences, 9(1), 120 - 130.

Mehra, P. (2015). More women workers can boost growth: IMF chief. The Hindu. http://www.thehindu.com/news/national/more-women-workers-can-boost-growth-imf cheif/article7622559.ece

Neumayer, E. and De Soysa, I. (2007). Globalization women's economic rights and forced labour. The World Economy, 30(10), 1510-1535.

Orbeta, A. C. (2002). Globalization and employment: The impact of trade on employment level and structure in the Philippines (No. DP2002-4). Philippine Institute for Development Studies.

Ozay, O. (2011). Implications of Trade Policy Changes on Gender Inequalities. Fe journal: Feminist Critique/Fe Dergi: Feminist Elestiri, 3(2), 33-53.

Peebles, D. (2005). Increasing gender inputs into Canadian international trade policy positions at the WTO. Status of Women Canada.

Pieters, J. (2015). Trade liberalization and gender inequality. IZA World of Labor.

Pramanik, M. A. A. (2010). Trade liberalization and its impact on Bangladesh Economy and Female Workers.

Ramsey, J. B. (1969). Test for specification errors in classical linear squares regression analysis. Journal of the Royal Statistical Society, Series B, 31, 350- 371.

Rehman, M. M. (2014). Trade liberalization and gender gap: Bangladesh experience. The journal of applied business and economics, 16(2), 57.

Riaz, W. (2014). Intra SAARC Trade and Non- Tariff Barriers. Pakistan Research Institute of Market Economy. Retrieved from http://primeinstitute.org/intra-saarc-trade-and-non-tariff-barriers/ 
Saure, P. and Zoabi, H. (2009). Effects of Trade on Female Labor Force Participation (No. 2009-2012). Swiss National Bank.

Schultz, T. (2006). Does the Liberalization of Trade Advance Gender Equality in Schooling and Health? (No.2140). Institute for the Study of Labor (IZA).

Seguino, S. (2000). Accounting for gender in Asian economic growth. Feminist Economics, 6(3), 27-58.

Seguino, S. and Grown, C. (2006). Gender equity and Globalization: macroeconomic policy for developing countries. Journal of International Development, 18 (8), 1081-1104.

Siddiqi, A. H. (2009). Finance of Foreign Trade and Foreign Exchange ( $5^{\text {th }}$ Ed.). Karachi, Pakistan: Royal Book Company.

Siddiqui, R. (2009). Modeling gender effects of Pakistan's trade liberalization. Feminist Economics, 15(3), 287-321.

Siegmann, K. A. (2006). Gender and Globalization in South Asia. South Asian Journal, 12, 50-64.

Spielmann, C. and Busse, M. (2005). Gender inequality and Trade. In proceedings of the German Development Economics Confrence, Kiel 2005(No.8). Verein fur Socialpolitik, Research Committee Development Economics.

Tariq, M. and Sultan, Z. A. (2008). Status of Women in SAARC countries: A Comparative Analysis. Gender Empowerment and Development, 29.

Tzannatos, Z. (1998). Women and labor market changes in the global economy: growth helps, inequalities hurt, and public policy matters (No. 20051). The World Bank.

Van-Staveren, I. (2005). Five methodological approaches for research on gender and trade impacts. ISS Working Paper Series/ General Series, 417, 1-40.

Verick, S. (2014). Female Labor force participation in developing countries. IZA World of Labor.

Vijaya, R. (2003). Trade, skills and persistence of gender gap: A theoretical framework for policy discussion. International Gender and Trade Network (IGTN).

Wacziarg, R. and Welch, K. H. (2008). Trade liberalization and growth: New evidence. The World Bank Economic Review, 22(2), 187-231.

Women Watch, (2011). Gender equality and Trade Policy, United Nations Inter- Agency Network on women and Gender Equality (IANWGE) Resource paper. Retrieved from http://www.un.org/womenwatch/feature/trade/gender_equality_and_trade_policy.pdf

Wood, A. and Riado-Cano, C. (1999). Skills, trade, and international inequality. Oxford economic papers, 51(1), 89119. 